\title{
Social Network Analysis: Recent Achievements and Current Controversies
}

\author{
Mark S. Mizruchi \\ Deparment of Sociology. L'muersin of Michigan
}

\begin{abstract}
Network analys has grown rapidly over the past two decades, but criticisms of the approach have increased as well This article focuses on several accomplishments and unresolved problems of the network approach. In the first section. I lllustrate the value of the network model in several substantive areas, focusing on studies of centrality and power. network subgroups, and interorganizational relattons. I then discuss three issues over which the approach has provoked controversy: the relation between network analysis and rational cholce theory; the role of norms and culture, and the question of human agency I conclude with some examples of how network theorsts are addressing these problems
\end{abstract}

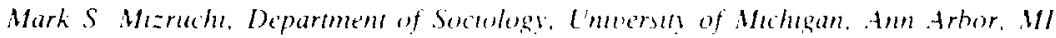

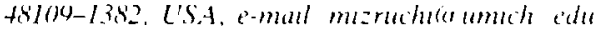

\section{Introduction}

Vetwork analysis has gained an increasing number of adherents over the past twenty vars. Research suggesting that social networks intluence the behavior of individuals and groups continues to multiply. As its popularity has increased. criticisms of network analysis have also proliferated. My purposes in this article are twofold. First. I provide brief overviews of the network literature in three important areas: centralıty and power; network subgroups; and interorganizational relations. The purpose of this discussion is to demonstrate the rapid progress that has been made in these areas durng the past decade. Second. I discuss three issues that are the sources of current theorctical controversies: the relation between network analysis and rational choice theory: the role of norms and culturc: and the question of human agency. I conclude with a brief discussion of future prospects for network analysis.

\section{Background}

Vetwork analysis has its roots in several theoretical perspectives. Some have traced

o) Scandinatian Sociological Association. 1994
It to psychiatrist J. L. Moreno (1934), who developed an approach known as sociometry. in which interpersonal relations were represented pictorially. Others have traced the approach to the work of British anthropologists John Barnes (1954), Elizaheth Bott (1957). and J. Clyde Mitchell (1964). And others (Berkowitz 1982) have even viewed network analysis as an outgrowth of the French structurilism of Claude Levi-Strauss (1969).

Network analysts can also be viewed as a subtype whthin the general framework of structural sociology (Wellman 1988). Structural sociology is an approach in which ocial structures, constraints and opportunities are viewed as having a more pronounced effect on human behavior than do cultural norms or other subjective states. The classical roots of structural sociology can be found in Durkheim. Marx. and (especially) Simmel. Simmel's influence on structural sociology stems from his concern with the formal properties of soctal life. For Simmel, social relations of particular types followed patterns that took on similar characteristics in a wide range of contexts. In any three-actor situation. for example. 
one actor will be successful to the extent that it can exploit a conflict hetween the other two. This pattern may occur among people. organizations or even countries. For Simmel, the forms and patterns of social relations were more important than their content. As Blau (1982: 276) put it. structural sociologists are more concerned with the proportion of isolates in at group [than] whether they are Jack and Jim or Jill or Joan.

Although differences exist among versions of structural sociology. most structural sociologists agree that objectuve factors are more significant determinants of hehavior than are subjective ones. Network analysis is a type of structural socology hased on an explicit noton of the etfects of socal relations on individual and group hehavior.

\section{Principles and methods of network analysis}

The primary tenet of network analyss is that the structure of social relations determines the content of those relations. Network theorists reject the notion that people are combinations of attributes or that institutions are fixed entities with clearly defined boundaries. Sociologists frequently use the terms society', 'government', and economy" and refer to individuals in terms such as lower middle class white Protestants who live in inner city areas and vote Democrat' (White, Boorman \& Breiger 1976 : 733). But these terms and categortes obscure what for network theorists is the primary 'stuff' of social life: the concrete webs of social relations that both embody and transcend conventional organizations and institutions. Government, for example. is not a fixed, unitary institution hut a number of subunits, often working at crosspurposes, whose members develop coalitions and disputes not only within and across agencies but also with various actors outside the state (Martun 1991). Understanding the social relations among actors both inside and outside state agencies would be necessary in order to explain the development of government policy, for example.

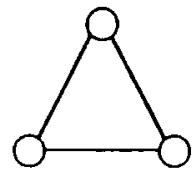

A

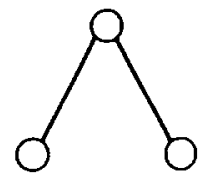

B

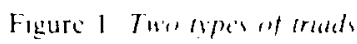

Simmel's discussion of dyad and triad [1917] 1145011 illustrates the promenple of has the structure of social relations affects theor content. Not only does the entry of a third person into a two-person encounter aller the nature of the relation between the firs! two people. hut the nature of the triad it sell is significant. In a completely connected traad. Illustrated in panel A of Figure 1 each actor meracts wh both other acturs In at herarchacal trial, such as that an pallel $B$ of Figure 1. the central actor is in d brokerage position with respect to the ather wo, hoth of whom must deal wath the hri. ker on order to communsate with the other These two structures, according to networh theory, create very different form af inter ation among group members. The poten. taal for brokerage allows the central actor in the triad to extract henefits from ans stuation in which the remaineng two astors attempt to communicatte (Freeman J494 Cook lYS2: Marsden 1482: Ciould \& Fer nandez 1989)

Network analysis is in theory applacille to virtually any substantive topic. Although network analysts have addressed a wide range of topics. three areas that hate received particular attention. hecause of their theoretical salience, are the effects of actor centrality on hehavior, the idente fication of network subgroups, and the nature of relations among organoatioms.

\subsection{Network and actor centrality}

During the 1950s and 1960s, a seres at experments, beginning at MIT under the direction of Bavelas (1950) Leavitt 1451: subsequently Hopkins 1904; Faucheux d Mackenzie 1966: Mackenzie 1976). found considerable differences in the character of group problem-solving activities acros 


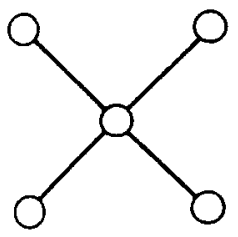

A

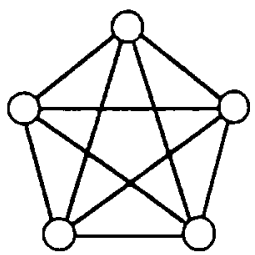

B
Figure 2. Herarchical and non-herarcheal sruchures

various communication structures. Of particular concern was the relation between an actor's centrality and his or her influence within the group. Leavitt (1951), for example, showed, using several types of communication structures, that the ditferences in influence between the most central and least central actor increased with the growing hierarchy of each structure. Figure 2 presents examples of classic hierarchical and non-hierarchical five-actor structures. In the hierarchical structure, known as the "wheel' (panel $A$ ), the central actor controls the flow of information between any other pair of actors. In the non-hicrarchical structure (panel $B$ ). which in this case is a maximal complete subgraph', in which all possible ties exist. any member of the group can communicate directly with any other member. Freeman (1979) has developed a measure of the centratization of a network, based on the difference hetween the centrality of the most central unit and the other units.' Freeman shows that using this measure, the hierarchical network in Figure 2 has a centralization score of 1 (the highest possible) while the non-hierarchical network in Figure 2 has a score of 0 (the lowest possible)

The rapid development of network analysis in recent years has led to the resurgence of both experimental and non-experimental research on the relation between the centrality and power of social actors. Marsden (1982). Cook et al. (1983). Markovsky. Willer \& Patton (1988), and the articles in the September/December. 1992 special issue of Social Networks provide examples of experimental and simulation work. Galaskiewicz (1979). Mizruchi (1982), Mintz \& Schwartz (1985), and Laumann \& Knoke (1987) provide examples of non-experimental work. all of which operate at the interorganizational level of analysis. Astley \& Zajac (199(1)). Brass \& Burkhardt (1992). and Krackhardt (1942) present examples of the role of centrality within organizations. Scott 11991), Cook \& Whitmever (1992). and Mizruchi \& Galaskiewicz (1993) provide reviews of this literature

Although several of these studies have demonstrated a positive association between centrality and power, the association between the two is more complex than the earlıer studies had suggested Simulations and experimental results by Marsden (1982. 1987). Cook et al. (1983). and Markovsky et al. (I988) have found that in certann types of structures (such as the restricted access structure presented in Figure 3), actors with high local centrality (Nieminen 1974), such as 7.8 . and 4 . may be more powerful than actors with high global centrality, such as actor 10.? In some situations, high centrality moht actually be a liability. In a study of the US electrical equipment industry price tixing conspiracy of the early lyols. Baker $d$ Faulkner (1993) found that central actors were the most likely to be found guilty of

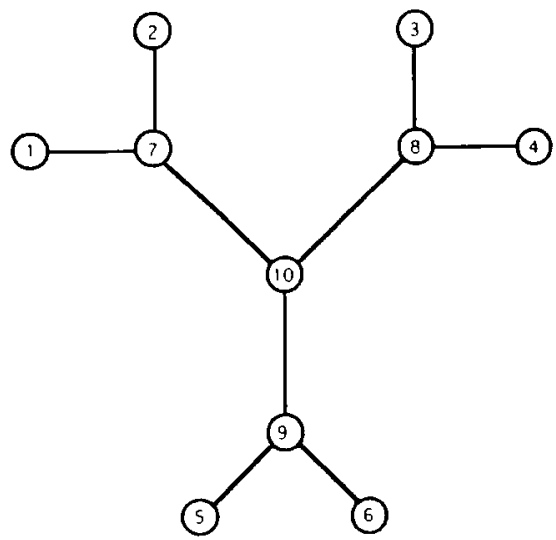

Figure 3 Ten-acter resurleted aceess metwork 
crimes, presumably because their central locations in communication networks made them more vulnerable to detection. Bonacich (1987) has noted that an actor's power may he greater if its ties are to relatively peripheral actors, who must then deal with the focal actor. In most measures of centrality actors with ties to peripheral actors will be less central than those with ties to central actors, however. This may explan some stuations in which centralits and power are not highly correlated. Studies by Cooket al. (1483) and Marsden (1987) have suggested that the centrality-power relation is affected by whether the networks are 'positively' or 'negatively' connected: in negatively connected networks. a tie heiween actors $A$ and $B$ precludes a tie hetween $A$ and $C$. This corresponds to the vituation described by Bonacich. and it is in negatuvelyconnected networks that Cook et al. fall to produce the expected association between centrality and power. In Cook et al 's networks, actors with high locial centrality are more powerful than those w'th higher levels of glohal centrality. Marsden (1987) shows that the relative power of actors with high global centrality depends on the extent to which central actors are able to form coalitions.

Despite the varlety of findings on the relation between centrality and power. most studies have revealed at least some substantavely meanungful association. They are thus conssstent with a key tenet of network thenry: that an actors postion in at social structure has a significant impact on its hehavior and well-being.

\subsection{Network subgroups}

A second major area withın network analyis is the identification of network subgroups. Most analyses have operated wathon two broad traditions, which Burt (1942) has labelled relational' and "positional". Relational models are based primaraly on graph-theoretic techniques (Harary. Norman \& Cartwright 1965). Their focus is on the identitication of cliques. densely connected regions of networks in which all or most actors are directly tied to one another. as in the non-hierarchical structure in Figure 2 (Alba 1973). Positional models are based primarily on mitrix algebratc tech- nuques (Lorrain \& White 1971). Thesr focu, won the identification of structuralty equmalent actors. pairs of actors with ties to the same third parties. The most prominent of these techniques is blockmodeling. developed hy Harrsonn White and his students (White. Bororman \& Breiger 1476: see the June 1942 spectal sisue of Soclal Netwroks for an wervew of recent advances). Blochmodels are hinary representatioms of relation matrices among actors in a network, permuted so that structuralls equivalent actors are clustered into square submatrices. or 'blocks". Blocks are identified as enther 'zeroblocks' or 'onchlocks' depending on the density of the tics among the actors withen them. In practice, acertan density cutoff point is used to distingursh zeroblocks from oneblocks. For example. in White et al is blockmodel of a biomedicial research network, the authors found that a cutoft density in the range of .10 to 511 yiclded similar results. The representatioms of structures can be reduced further through clusterng of structurally equin. alent blocks into two by two matrices. The patterns of block sdentify different types of social structures (White et al. 1970) Consider. for example. a model in which the raw data are friendship chocess so that actors maty name particular others as frends but the ties may or maty not be reciprocated If the matrix. when reduced to a 2 ? blockmodel. contans a zeroblock in the second column of the first row and one. blocks in the other cells. as in the following representation.

It would represent a hierarchical structure in which ties go from lower to higher-status actors but not vice versa (White et al. 1470 : 742). In this example. the high-status actors (row 1 ) chooue other high-status actors (column 1) but do not choose low-status actor (column 2). The low-status actors (row 2). on the other hand, choose both high-status and other low-status actors fcolumns 1 and 2 respectively). Blockmodels are not the only technumes that employ structural equivalence as a basis for clustering. Other widely used techniques, such as tactor 
analysis (Allen 1978). multidimensional saling (Lewne 1972: I.aumann \& Papps 1470). and the non-discrete structural equivalence clustering techniques emploved hy Burt (1982), often vicld cluster smilar to those produced by hlockmodels sece Breiger. Boorman \& Arabie 1475 on blockmodels versus multidinemenonal scal|ngl.

Proponentsof virtuallyall clusterng technupues agree that members of particular dicues or clusters should displat smomarattetudes and behaver. But since the graphtherretce cliques are based on direct ties among actors, while blocks and other portunal clustersare based on structural equs alence. the two modele lead to difteremt predictions about the sources of interpermal influence and ymilarity. Relattons in diques are based on cobestice tees hetween ators. In the coheson models, whach hate been the most wedely ued by network andInst , those whointeract directls will tend te intluence one another. The itructural eyumalenec moded lead to two porshle interpretateons. Onc. presented hi Fredkin $(19 x+$ ) and Mlorucha (1943), suggests that seructurally equivalent actor are likely to hehave smiarls because they hale several common sources ot disect influence. An diternative argument. presented by Burt $(1487)$. suggests that structurally equis alent acters, beciuse they fontly oceups the same portions in social structures, compete for the tavor of occupants ot other postems Beciase of thiscompctuton actorsarelikels to momic attons taken bs thes structurally equariant peers.

Buth the cohesson and structurat equasalence models have recesved comblerable veport in the literature. A few ot the many examples that support the cohesion model are sudies by Moore (1979). Fredkin 148t), and Latumann \& Knotic (1987). Studes supporting the structural equasalence model include those bs Burt (1987). Johnom (1486), and Galaskiewice \& Burt (194)1. Some studies have found suppert tur both approaches (Mizruchi l4y2. 1493).

\subsection{Network analysis and interorganizational relations}

Fur many years, a frequently mooked criteusm of network analyse was that its adher- ents had been successful in presenting clegant mathematical descruptions of social tructures but they had been less successful in demonstrating that those structures have actual behavoral consequences. In no area has thus critiom been more prominent than in the study of interorgancational relations.

Although a few early studies had shown that centrality in interorganizatomal networks was assoclated with identifiable organuational outcomes, including an organtzation is likelihood of political success (Gialarkiewicz 1479) and its investment stratcegses (Ratclitt losil). there were tew such demonstrations pror to the mid-19sis. Since that tume, however. there has been at proliferation of studes suggesting that a firm i postion in intertirm networks influences as behavor. Much of this work has appeared in busmess management publications and has been concerned with the effects of board of director composition on manageral strategaes. Boards of directors are sementicant becallse a firmis derectors otten st on the boards of other firms. creatung what are called interlocking direcwates Interlock networks are the most studed torm of interorganizational relations. Although there are sereral competung vew of the role that anterlucks platy. many theormabelaete that thes promde an indicitor of intertirm rocial relations that If the predictions of network theory are accurate. should influence the behavior of tirms (ree Petterea 149: Mizruch ly4t tor revelws of these modelst.

Several studes of hoard composition withan the busmes management literature focus on the role of outside directors. Beciuse outside directors are usually affilaated with other corporatrons. this varable also proveles an mdxator ot the extent to whoch a firm is integratced into interfirm networks. The organizational literature uggeents that these tles hatle a signiticant impact on corporate strategles. In a study of the use of 'greenmatl'. the provate repurchase of company stock. Kosne (1987) tound that firm that resisted greenmall had more outside directors and more directors who represented firms with which the focial tirm had transatetons than dad firms that pald greenmal. Studes hy Cochran. Wood d Jomes (1485). Singh a Harranto (1989). 
and Wade, O'Reilly \& Chandratat (199()) found that the proportion of outside directors on a firm's hoard was positively associated with the existence of golden parachute' policies for the firm's top executives. "Davis (1991), in a study of firms' adoption of takeover defenses (known as 'poison pills'), found that firms were more likely to adopt poison pills when they shared directors with firms that had already adopted. Baysinger. Kosnik \& Turk (1991) found a negative association hetween the proportion of outside hoard members and firms research and development expenditures. Clawson \& Neustadtl (1989) and Mizruch (1992) found that director interlocks influenced corporate political strategies. Haunschild (1993). Flıgstein d Markowitz (1993), and Palmer et al. (1993) found an association between interlocks and firms' participation in mergers and acquisitions. Boeker \& Goodstein (1993) found that firms with a higher proportion of outsiders on their boards were more likely to appoint CEOs from outside the firm. And Stearns \& Mizruchı (1993; Mizruchi d Stearns 1994) found that the presence of representatives of financial institutions on a firm's hoard influenced both the amount and type of financing the firm used.

What are the processes by which these networks are purported to influence firm behavior? One example is provided by a recent study of corporate political action (Mizruchi 1992). The concern of the study was the similarity of political behavior between parrs of large US manufacturng firms. Among the network variables expected to lead to similarity of hehavior were the economic interdependence of the two firms, whether the firms stock was held by the same institutional investors, and two types of director interlocks. those created by direct ties between the firms, and those in which the two firms each shared directors with the same third firm. Focusing on the interlock effects, the argument proceeded as follows: firms enter into a political situation with a set of both clear and uncertain preferences. Other things being equal, the leaders of interlocked firms are more likely to communicate with one another than are the leaders of non-interlocked firms. Among the ideas that may be communi- cated is information about political can. didates. Exposure to either positive of negative information from other firm rep. resentatives about candidates may affect a firm's decision-making. When two firms share interlocks with several additional firms (indirect tles. which I interpreted as an indicator of structural equivalence), the! are exposed to several common sources of information. This further increases the likelihood that they will contribute to the same candidates. The findings from this studs indicated that the presence of indirect ties between firms was more strongly associated with contributions to the same candidates than was the presence of direct ties. The smultaneous exposure to several common sources of information may he one expla. nation for this.

Even ordinary economic activities mal be affected by interfirm relations. Uzza (1993). for example, in a study of the garment industry in New York. found that firms that were about to relocate their facill. tles offshore warned their suppliers month in advance. despite the fact that such knowl. edge created an incentive for the suppliers to shirk on their orders. Uzzs attributed thu apparently irrational behavior to the clowe social relations among members of the industry

Granovetter (1985) has provided a general theoretical model within which to account for such behavior. Departing from Oliver Willamson's ( 1975 ) version of transaction cost economics. Granovetter argues that the social relations that develop among customers and suppliers often mitigate, of completely nullify, the opportunism that. according to Willamson, characterizes market transactions. Williamson (1991) is able to account for non-opportunistic behatior with the concept of asset specificity. in which repeated transactions create incentives for maintaning the relations, despite the reduced opportunities for opportumstic behavior. But these situations are seen b? Williamson as aberrations rather than is basic components of his model.

\section{Structural sociology and rational choice theory}

The contrast between the Granovetter and Williamson models of interfirm transactions 
raises the issue of the relation between network models and economic models in general. Structural sociology developed in the United States during the 1970s as an alternative to the normative model that dominated the field during the 1950)s and 1960s. This model, hest characterized by the work of Talcott Parsons (1951), suggested that the basis of social order was in shared generalized beliefs (values) and expectations of behavior (norms). These values and norms, according to the model. were internalized, primarily through childhood socialization. To the extent that this socialization is successful, human action voluntarily proceeds according to the society's values and norms. ${ }^{4}$ Structural sockology, with its emphasis on the constraints and opportunities that influence behavior. tended to de-emphasize or discount entirely the role of internalized norms. People may behave according to norms not because they have internalized them. but because they fear the sanctions that could apply if they violate them.

Because structural sociology and network analysis can be viewed as alternatives to normative sociology. it would be worthwhile to consider the relation between structural sociology and another widely used alternative to normative sociology: rational choice theory. The rational choice critique of the normative perspective shares many similarities with the structural critique. Rational choice theorists are also concerned about the difficulty of distinguishing between internalization of norms and fear of sanctions. When we observe customers in a store paving for their goods (and refrainıng from stealing), we have no way of knowing whether they do this because they have internalized the norm that stealing is wrong or whether they simply fear the consequences should they be caught. Because it is impossible emprrically to distinguish the two accounts, and because even normative theorists acknowledge that cases of the latter do occur. rational choice theorists tend to assume that fear of sanctions rather than internalization of norms drives normatively prescribed behavior. Rational choice theorists thus agree with structural theorists that in the absence of unambiguous evidence that actors internalize norms, there is little analytical benefit in assuming that they do (Hechter 1987). Moreover, both models are concerned with the opportunities and constraints that actors face. Hedström's suggestion (1993: 167) that rational choice theory usually assumes that variations in individual behavior are explained by differences in the opportunity structures actors face, rather than by variations in the internal "makeup" of the actors" could he sand of structural sociology as well.

Where structural sociology and rational choice theory diverge is in their analysis of the determinants of behavior. Rational choice theorists usually assume that individuals enter social situations with exogenously formed preferences (utility functions) that remain constant throughout the social encounter. This assumption has enabled rational choice theorists to develop powerful and rigorous models of social outcomes. but these models are often suspect empircally because of the simplifying assumptions necessary to generate them. Structural sociology has no built-in assumptions about the rationality of human actors. But there is nothing in the structural model that precludes the assumption of human rationality. and many structural sociologists have assumed. either implicitly or explicitly, a rational actor model (Burt 1982: Granovetter 1985: Mizruch 1992). The primary differences between the structural model and the rational choice model are that in the structural model (1) human preferences are viewed as endogenous: that is. the formation of preferences is taken as something to be explained; and (2) human action is vewed as affected by explicitly defined social structures.

As an example of the differences between the two perspectives. I have presented a distinction between what I term 'individual' and 'structural' interests (Mizruchi. Allison \& Potts, 1994: see also Burt 1982: ch. 51. Because network theorists argue that all interests are endogenous. I use the concept of individual interests primarily as an analytic tool. An individual interest is a preference that an actor holds in the absence of external constraints. A structural interest is a preference held by an actor subject to social constraints, which differs from what 
the preference would be in the absence of those constraints. A firm that changes its position on a political issue to accommodate a powerful customer is revealing a structural interest. There is nothing in this model that prevents the firm from being viewed as a rational actor. But the firm's rational action is viewed as occurring within a system of constraints, identified by the social structures within which the firm is embedded.

Consider a case taken from a current study of political decision-making (Mizruchi, Allison \& Potts 1994). Let us assume that an actor enters a political situation with a position on an issue and a level of salience. the latter based on how important the issue is to the actor. Let us also assume that the actor is embedded in a network of dependence relations, in which others on whom the actor depends may hold opposing political positions. If an actor determines that the need to maintain positive relations with others upon whom he or she depends exceeds the salience of the issue, he or she may decide to switch to the other actor's position. In the study cited above, we conduct a simulation that illustrates the extent to which political outcomes can be affected by even small levels of network dependence. Although the model contains certain rational choice elements of decisionmaking, the social structure alters the political outcomes in systematic ways. These outcomes cannot be understood without an examination of that structure. For related examples, see Marsden's (1982) modification of Coleman's (1990) model of power as well as Stokman and Van den Bos (1992).

\section{Problems of network analysis and structural sociology}

Structural sociology has revitalized several areas of sociology, including social movement theory, the study of social inequality. the sociology of development, and even research on attitude formation. The structural approach has forced researchers to consider aspects of the social world that had previously received insufficient attention. but a single-minded focus on structural constrants renders our explanations incomplete in two areas: the origns and content of preferences and the effects of human agency. These areas have been a primary focus of recent criticisms of network analysis.

\subsection{The role of norms}

Despite the criticisms mentioned above. one advantage of the normatue model is it explicit attempt to identify hoth the origins and the content of people's worldviews. Network theory can explain why. given that a person's friends are political liberals. the person is likely to hold liberal positions as well. As noted in the previous section, the endogenetty of preferences is an advantage of the structural model over the rational cholce model. But the network approach cannot explan why particular groups of people hold liberal views in the tirst place. Suppose that an actor is a member of the working class in an industralized nation. Members of the working class have historically tended to support labor or socialist parties. It is not always possible to determine whether an individual supports labororiented candidates hecause it is in his or her individual interest to do so (1n other words. that this support would occur in the absence of intluence by others). or whether the person supports such candidates because of influence by others. Some versions of the structural model can explan why an actor would have an interest in voting for labor or socialist candidates even if he or she were not directly influenced by others. In this case, one votes according to one's economic interest. But the network model cannot account for this support in the absence of influence by others, hecause it has no way of determining the content of one's preferences. [Even the assumption that is possible objectively to identity it voter's economic interest is problematic. One could argue, for example, that in the long run, protectionist trade measures might harm the economy. which might harm the workers whom the measures were designed to protect. This possibility might explain why in the United States a signiticant proportion of workers support conservative political candidates. I 
It is possible to argue that everyone's preferences, no matter how isolated they appear, have been influenced by others at some point. But if a preference is the result of an earlier socialization experience, then the structural model loses much of its analytic advantage over the normative model. since the person's preference is guided by internalized norms rather than ongoing social relations. In the above example, the worker's support for the labor-backed party might have heen cemented during his or her childhood socialization. Moreover, many structural arguments are vable only hecause of an implicit assumption of wellestablished norms, although it is not necessary for actors to internalize those norms, as long as they agree to abide by them (Sciulli 1992). Baker's (1984) study of price volatility on the floor of the Chicago stock exchange is a good example. Baker found that prices fluctuated more widely in large groups than in small groups hecause tace(1)-face interaction among traders was more difficult in the larger groups. But Baker's study works only if we assume that partocipants in the stock exchange agree on the rules of trading

If it is possible to identity an actor's politcal preferences and if those preferences predict behavior even in the absence of clear interpersonal influence. then an attor's personal attributes, such ats class or race, may generate accurate predictions. So we can predict that a member of the working class will support a labor party simply by noting that the person is a member of the working class. In such a case, a structural model may be useful, but a network model. In which the use of categories is eschewed. maly be unnecessary. Even if categorical thinking often obscures the social processes by which preferences form and action occurs. it may also pronde a predictive power that on some cases exceeds that of a network model.

This argument forms the hasu of a recent critique of network analyss by Brint (1492). Focusing specitically on the work of White. Brint suggests that categories often form the basis of social identities and roles that have various normative dictates that pro. vide hases tor action. In his reply. White (1992a) does not deny that norms are nec- essary for social structures to operate hut argues that social structures are a necessarv precondition for the generation of common normative frameworks. One reason that people from different groups within a particular society (urban youths versus middleaged suburbanites. for example) have difficulty communicating is that their social isolation has given them little opportunity for common experiences and understandIngs.

The concept of structural equivalence in fact was first developed to capture the concept of a role. It was later discovered that the mathematical representation of structural equivalence was unahle to do this hecause structural equivalence was defined in terms of ties to the same particular actors (so that two fathers could be structurally equivalent only if they had the same children; see Winshıp [1973] 1988). Network theorists have developed the concept of role equivalence to deal with this issue Role-equivalent actors need not be tied to the sime other actors but instead need only be involved in similar types of relations with similar types of actors (see. in addition to Winship's article, Salter 1478: White de Reıtz 19S3: Burt 1990: Borgatti \& Everett 1992: Mizruch 1993). The concept of role equivalence and its varlants (including automorphic and regular equivalence) acknowledge the fact that social roles are likely to be accompanied by normative prescriptions. The significant point is that these roles are detined in terms of one's position in a social structure

The dehate between network theorists and proponents of the Brint posituon is unlikely to be resolved soon but the volume of dialogue has increased significantly in the past five vears. Those who emphasize the role of culture frequently acknowledge the importance of social structure. And network analyst increasingly acknowledge the existence of gaps in structural explanations that may require cultural or normative accounts to fill. Still. even if proponents of a particular position admit that the alternative has something to offer, the debate continues to raise an issue of analytical strategy: that is. which approach. which starting-point, provides more explanatory leverage? Thus question also remains open 
What can be sand is that as a research strategy. network analysis has demonstrated considerable analytic power."

\subsection{The role of agency}

A second problem shared by hoth network analysis and structural sociology in general is their treatment of human agency. (The normative model often fares no better on this score. but that is irrelevant here. I Structural theorists emphasize the extent to which human actions are affected by constraints and opportunites. But they have failed to develop a comprehensive model of human agency.

The claim that structural models often have underdeveloped conceptions of human agency has been rased by several theorsts (Giddens 1984: Hatnes 1988: Cohen 1989; Brint 1992). One explicit early attempt to include agency in a structural theory was presented by Burt (1982). In Burt's model, social structure affects action. hoth indirectly (through its effect on actor interests) and directly. Action is then viewed as potentially modifying the social structure itself (ibid: 9). Critcs (Haines 1988: Cohen 1989) have argued. however, that even Burt fails to develop an explicit model of exactly how social action modifies social structures. Haines (1988). drawing on Giddens, has emphasized the recursive nature of human action, in which actions simultaneously are affected by and recreate social structures. Several recent works by network theorsts have moved us closer to a theoretically rigorous model of agency. Two works in particular. those hy Burt (1992) and White (1942h), have dealt explicitly with the issue."

Burt is concerned with how actors identify and take advantage of opportunities in social systems, vacancies that he reters to as 'structural holes'. This attention to vacancies in social structures has been a significant component of White's work (1970, 1992a; White, Boorman \& Breiger 1976). By filling a hole, an actor increases his or her likelihood of upward mobility but he/she also alters the structure so that a hole no longer exists in the same position. Burt shows how actors who are skilled at filling structural holes and in maximizing the efficiency of their socral ties (by mint- mizing redundant contacts, for example). have greater upward mobility withın an organization than do actors who are less successful at both using and altering the social structure.

White (19y2b) has attempted to reconceptualize human action in terms of iden. tities seeking control. Identities are any form of activity to which we can attribute meaning. Persons exist only as ensembles of identities" (White 1942a: 210). Identities exist only to the extent that actors are able to differentiate themselves from others. Human action is a constant search for miches withın which to sustain identities. Through the quest for control, actors continuously create and recreate social structures. In his earher work on markets. for example, White (1988; Leifer \& White 14\$7) argued that rather than consistung of a series of simular firms producing a similar product. markets consist of a variety of producers differentiated by the volume and quality of their products. White demonstrates mathematically that markets can reproduce themselves only to the extent that producers are able to carve out uniqui niches for themselves.

\section{Conclusion}

Structural sociology and network analysis with their emphasis on objective. obser. able social forces and their abilıty to generate falsifiable hypotheses. have provided an improvement over some of the problematic aspects of traditional normative models. But structural models have been limited by their inability to handle the cultural content of social action as well as by their underdeveloped conception of human agency. The above discussion suggests that network analysis holds particular promise for dealing with the issues of culture and human agency that have posed problems for structural sociology in general. With its emphasis on concrete social relations rather than categories, network analysis presents a more dynamic conception of social action than do either the traditional normative or structural models.

It is important to recognize that network analysis can complement as well as supplant existing perspectives. A good example of how network analysis can extend the anat- 
Iytic power of an alternative theory is its relation to what is perhaps the most widely held socological model of organizations: institutional theory. Institutional theory is based on the promise that organizations. rather than providing rational solutions to well-defined problems, are equally likel! to reinforce societal symbols, or myths (Meyer \& Rowan 1477: Powell and DiMaggio, 1941). As part of this reinforcement, organizations contınually seek legitimacy from ther external envronments. Rather than a quest for an objective notion of efficiency, organizational hehavior becomes a quest for legitumacy. An important statement of this model hals been preiented by DiMaggio de Powell (198.3) DiMaggio and Powell argue that organizational forms in modern socteties come to resemble one another, not hecause these forms are necessarly the most efficient. but rather because the need for legitumaty requires them. DiMaggio and Powell identify three types of this "isomorphism" : coercwe. in which organizations develop structures to conform to the expectations of other organizations on which they depend: mimetic. in which organizations, under conditions of uncertanty. simply adopt the structures of therr peers: and normative, in which similas soclatization experiencer lead to worldviews that generate smular types of prescribed solutions to organizational problems. What the DiMlagglo and Powell model lacks, and what network analyss can proside, is a detaled conception of the processes by which this isomorphism is transmitted. Coercive somorphosm is likely to occur in situations of direct. cohesive relations among organizations. Mumetic isomorphism is likely to occur when organzations observe and try to keep pace with thes structurilly eyuivalent or role eyurs. alent peers. Network theory cammot tell w why there are particular symbols and myths that organzations strive to reuntorce. But It can explain why certann forms as opposed to others are adopted, regardless of whether they are objectively more effickent. In that sense, although network theory mat require an institutional or smmlat perspective to completely alcoount for it phenomenom, institutional theors may require network theory as well. The latter can render institutional concepts both more concrete and more rigorous.

In fact, its versatility is one of the great strengths of network analysis. Not only can network analysis he employed in conjunction with institutional theory but it is compatible with and capable of extending the population ecology and transaction cost models as well. The population ecology notion of an organizational niche has been reconceptualized within the terms of structural equivalence by DiMaggio (1986: see also Burt 1992). And the concept of transaction costs has heen formalized in analyses of brokerage (Marsden 1982) and broadened in Granovetter's (1985) discussion of embeddedness. The connection between network analyss and the resource dependence model is already well established and need not he repeated here (Burt 1983; Pfeffer 1987: Mizruchi 1992)

Although network analysts contunue to grapple with the theoretical problems discussed above, there is reason for optimism. Increased attention to the issue of agency has led to signiticant advances within the past five years. As theorists take advantage of the stochastic assumptions behind network models, progress on the agency-structure dilemma seems imminent. Greater efforts to acknowledge the importance of culture have also proven encouraging [see. for example. White's recent (1993) work on art]. As White has demonstrated, network analyss can be valuable in examining the contexts through which culture is transmitted.

Network analysis is one of the fastest growing approaches in the social sciences. The evidence that human action is affected hy the social relations within which actors are embedded continues to mount. I have presented only a small piece of that evidence here. The slac of the pere will continue to grow

\section{Acknowledgements}

Thas aceach was supported by the LS Nituonal Sicence Foundation (erant \#SBR-431184+43) The wuthor even:k has thanks a Julad Adams, Peler Hedstrom. Rethard Swedhers, and three anomsmous revewers for thesr comments on eatrler distls

Recerted Mlat 1494

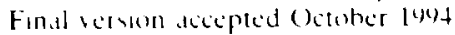


Notes

Thes measure has three varlatums. based an Freeman's three concepteons of centralits descussed below: The hatc computalon movelse summing the defferences between the centrallu! of the most central unit and atl other unit and then dividing this sum by the maximum pousble sum of differences for a network of that we

Although there have heen several adiances in recent vears, the most comprehenswe theoretical statement on centraluty remams Freeman i (1974) work. Freeman disungusslad threc typer

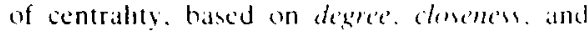
betweenness Degree reters to the number of direct teen between an actor and other ators m a network Closeness relers to the extent to when an actor can reach a large number of other actore in a small number of step And hetweennes refers to the extent to which an ator creates a unique path between wher actors, of that the latter must deal with the former if the are 10 communkate the detiniteon it eentralits presented by Bonacsh (1972. and elathorated and modilied in 1987) has aloobesn heghly influcental See also Maruchi et al (14sin). Stephement de Zelen (1484), and Fredkin (144)

'Golden parachute agresments are lucratue severance patialgen that are guaranted to chet executses in the erent the are fired. These plane prohterated in the (is buvines world durme the $1981 \%$

tOf course. the moded ud tar more complex and wared than thes brect decount uggents But It dad place a mapor emphess on the role of learned norme in mflucoung behasu

"It is necessars to consuder the rolle ol culture to understand the content of normatue prescriptons arsociated wh secial relatom one conceptoon of culcure that could he usetul tor structural socologey has been presented by suidler (1986). Swidler argues that culture cin best be understood as a sistem af learned hehaviner that actors use to negottate their datly atovites These behaviors are learned in epecitic bocal context and must be contanuously remforced in these contexts What is baluable dhout the model is the vere that norme are not necestarils part ot a generalized value whem but rather develop in spectic hehavoral contexts

"See also the artacles in Weese de Flap ( I y9(1). which include discussuns of method for handling changes in network over lame

\section{References}

Alta. R D 1473 A (iraph-Thourctic Dedmotion of a Socsometric Cleque Journal of Math. emateal Sorodosy 3, 113-120
Allen. M. P 1478. Economic Interest Groups and the corporate Elate Structure fercul Solence Qlearterly $58.597-015$

Astley. W. G d Ziljac. E J 1990 Beyond Dyadic Interdependence Mrganzatum Srudter $11,481-5011$

Baker. W' E lust the Soctal Structure of a Nateonal Securities Market demertican folurmal of Socologer 89 . 775-811

Bater, W E d Faulther. R. R 1943 The Sucial Organazation of Conppiracy lllegal Networh in the Heaty Elcorrical Eyupment Industr

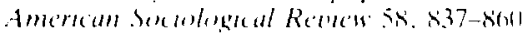

Barnes. \&. A. 1954. Class and Commuttees in a Norweglan Island Parmh Hamam Relatmom $30-5 x$

Barelas, A 1950 Communcatton Pattern in

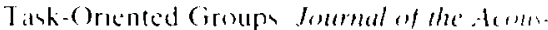

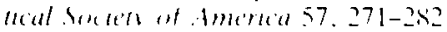

Basunger. B D. Kusnk. R D d Turk. I I 1941 Filects of Buard and (Ownershep Strue. curcon corporate Red strategl fodem in Manugeme'ne Jeurnal 34. 2015-2it

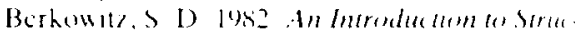
mural fladhes Toronto: Butterworthy

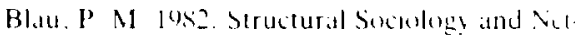
work Analyse in Orervesu in P l

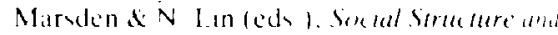

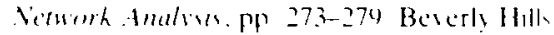
CA Sage

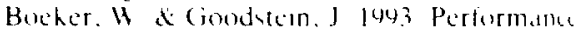
and Successer (hesce ithe Moderateng Eltcel at Ciovernance and (Bunership teatems of Manageme'nt Jonernal 3h, 172-15h

Bondach. P l972 Techmlate for Andwan! Orerlappong Memherships in H Commer

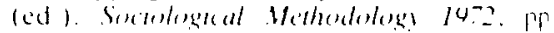
170-185 Sun Francenco Jomer-Bas

Bonacach. P 1987 Power and centralats I Famelyol Mcasures Amercan formalef hent. olege y? $117011 \mathrm{k} 2$

Borgatte S P d Everett. M ( ; Jue l he

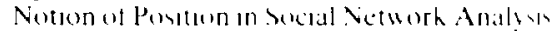

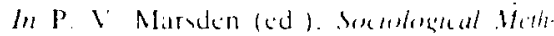
odeleng two? Pp 1-35 Ovford B.wl Blachucll

Bott. E 1057 Famble and Sindal Somorh Roles.

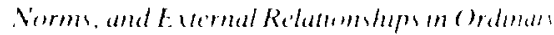

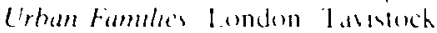

Braw, D J \& Burhhardt, M E louz Contralles and Pows in ()rgantations In N Nohriad

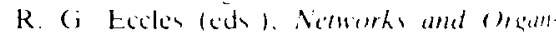
ratoms. Pp 191-215 Boston. Harsard Bus. ness Schenol Press

Breger, R. L. Boorman, S A a Aralue. P' 1475 An Algormthm tor Clusteruge Relatumal Data wath Applacateme 6 Sertal Netmork Analyes and Comparmon with Multadmen.

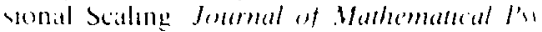
chologe 12. 328 353 
Brint. S. 1992. Hidden Meanings: Cultural Content and Context in Harrison White's Structural Socmology. Socolengad Theors 141. 14t 2018

Burt. R. S. 1982. Toward A Siructural Therom of Actom Ne'work Mudels of Socul Siructiore'. Perceptom. and Actom Nou York Academic Press

Burt. R. S. 1983. Corporale Protils and CooplaIarn New York Academic Pren

Burt, R S. 19ric. Sucial Contugion and Inruvatuon: Cohesson versus Structural Eyurval.

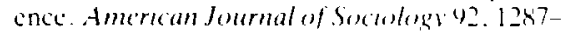
1335

Burt. R S 1990 Detecting Role Fyumalenos Sormal Nemorki 12.83-47

Burt. R S 1902 Sermatural Heles The Sered structure of Compentum Cambridge. MA Harvard Linversity Pres

Clawom. D \& Neustadtl, A losit Interlochs, PACs. and Corporate Conservatiom tmencan foumal of Socology (4. 744-773

Cichrin, P. L.. Wood, R A dones, I B 1485 The Compostion of Boirds of Derectors and Incidence of Golden Pariachuts teadem

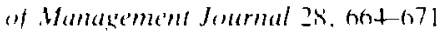

Conen. I lusy Serucauratom Therery London Macmillan

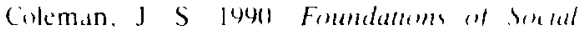

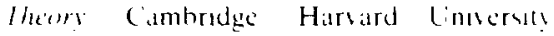
Press

Cook, K. S 1482. Network Structures from an Fxchange Perspectave In P V' Maruden d

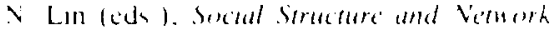
flualses. PP. 177-144 Beverly Holls. CA Sige

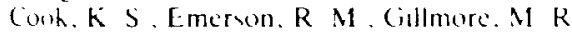
$d$ Yamagssh. I 1483 The Iostrihuteon ot Power in N.Person Exchange Nemorh. Theory and Experamental Resuld Amerem Journal of Sonology $84.275-305$

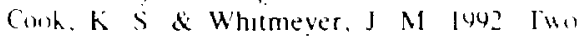
Approdiches wo Soctal Structure Exchange Theory and Network Analyos thmal Re're's (i) Sociology 18, 109-127

Dass. (i F 1941 Agenu Without Proncipices" The Spread of the Poison Pill Ihrough the Intercorporate Network Admmirame Sceme Quarterly 36. 583-613

DiNiggeo. P J luxh Structural Analises of Organzational Field A Blockmodel Approach. In B M Staw \& L L cummonge led 1. Research an Orgamzatuonal Behatest. Pf 335-370 Greenwich. ("T JAI Press

DiMiggso. P J \& Powell. W W 198.3 I he Iron Cage Revisited Institutional Isomorphism and Collective Rationality in Urganizational Ficlds. American Soculogical Revien 48 . 1471611

Faucheux, C \& Mackenzle. K D lono lash
Dependeney of Organizational Centrality: Its Behaveral Consequences Jeurnal of Exper. imenual Sucial Psychology 2, 361-375.

Fligstern. N d Markowitz. L 1993. Financial Reorganization al American Corporatuon m the lyxik. In W. J. Wilson led.). Soctologe and the Puhlic Agenda. pp 185-20k. Newhur! Park. CA Suge

Freeman. [. C. 1474. Centraluty an Sucial Networks: I Conceptual Clarification Suctal Ve'twerk' $1,215-239$.

Fricthin. N. E lust Structural Cohesem and Eyuaralence Explanation of Social Hom. ogencisy Socologeted Methed and Revedareh 12. $235-201$

Friedkin. N E lyyl Theorctical Foundation. for Centrality Measures tmercan fourmal af Socolege 46. 147x-1504

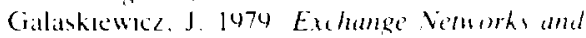
Commumer Pollacs Bereriy Hall Sage

Galashemicz. J de Burt, $R$ S. luyl Interorganizaton Contagon and Corporate Phitanthropy Admmastrume Scatence Quarterls in. $x \&-1115$

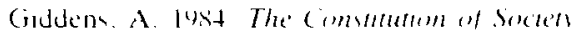

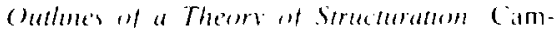
bridge. England. Pollty Press

Gould. R V A Fernandez. R M luse Strustures af Alcdation A Formal Approach w

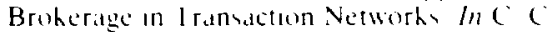

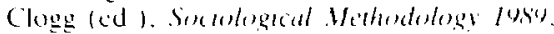
PP su-126 Washingter. DC Amercion Socologicat Amoletation

Granoveder. M S 1455 Economme Acturn and Social Siructure Ihe Problem at Embeddedness Amernoan Jourmal of Soweleges 41. $+\$ 1-5111$

Hannes. I l lysis Social Network Anolym. Structuration Theors, and the Holsm-IndtWdualsm Debate Secal Verworh 111. 157182

Harary, F . Vorman. R d Carmenght. D luns

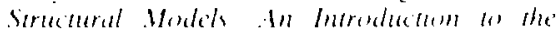

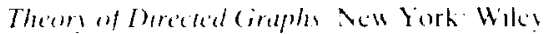

Haumchuld. P R 149; Interorganiatuonal Ime. tatem I he Impact of Interleckson cirporate

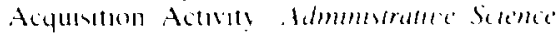
Guarlerh 3x. 5nt 5u?

Hechere, 11 1987 Primuples al cirmap

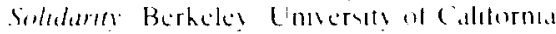
Prew

Hedutrom. P leys Introduction to I ha Spectal

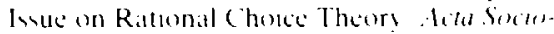
lesica 3o, 167

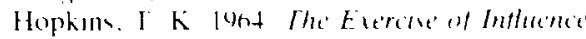
in Simall cirmups Totoma V I Bedmunster

lohnoon. J C gusin Soctal Networhe and Innervatuon Adoptuon A lonk at Burti (ine of

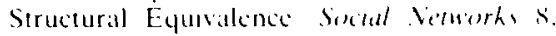
$3+3-364$ 
Kosmik, R. D. 1987. Greenmaıl: A Study of Board Performance in Corporate Governance. Admuntrantue Science Quarterly 32, 10.3-185.

Krackhardt. D. 1992. The Strength of Strong Ties: The Importance of Philos in Organizations. In N. Nohria \& R. G Eccles (eds.). Nerworks and Orgamianons, pp. 216-234. Boston: Harvard Business School Press.

Laumann, E. O. \& Knoke, D. 1987. The Organizanomal Suate. Soctal Chonce in Namonal Policy Domams. Madison: University of Wisconsin Press.

Laumann. E. O \& Papp, F. U. 1476. Networks of Collecture Action. A Perspectie' on Communuty Influence Sysems. New Jork: Academic Press

Leavitt, H. J. 1451. Some Effects of Certan Communcation Patterns on Group Performance. Journal of Ahnormal and Socal Pstchology t6. 3x-50

Letfer, E. M \& White, H C. 1487 A Structural Approach to Markets. In M. S. Mizruch de M. Schwartz (eds.). Intercorporate Relattons. Pp 8.5-108. New York: Cambridge Universit! Press.

Lev-Strauss, C 1969. Elementary Structures of Kinshup. Boston: Beacon

Levine, J. H. 1972. The Sphere of Intluence. Americar Soctulogical Revew 37, 1 $1+27$

Lorratn. F. \& White. H. C. 1471 Structural Equivalence of Individuals in Social Networks Journal of Mathematcal Soctology 1. f9-8')

Mackenzle. K D 1970 A Theory of Group Structures New York: Gordon and Breach

Markovisy. B. Willer. D \& Patton. T 1988 Power Relations in Exchange Networks Amercan Soctologtcal Revilew 53. 2201-23n

Marsden. P. I 1482. Brokerage Behavior in Restricted Exchange Networks ln P V Marsuen \& N. Lin (eds.). Sental Seructure and Network Analysis. PP 201-218 Beverly Hills. CA: Sage

Marsden, P. I' 1987 Elements of Interactor Dependence. In K. S. Cook (ed). Social Exchange Theory. pp. 13(1-14x. Newhury Park. CA: Sage

Martın. C J. 1991. Shifung the Burden The Struggle Oeer Groulh and cirporate Taxaton. Chicago: Universty of Chicago Press.

Mever, J. W. \& Rowan, B 1977 Inst1tutionalized Organizations: Formal Structure as Myth and Ceremony. American Journal of Soctology 83, 3401-363

Mintz. B \& Schwartz. M 1985 The Power Siruciure of American Busmess Chicago Untversity of Chocago Press

Mitcheli, J. C. 1969. Soclal Nerworks in Lirban Situatons. Manchester. UK: Manchester Untversity Press
Mizruchı, M S 1982. The American Corporate Network: $19(1)+1974$. Beverly Hills. CA Sage

Mizruchi, M. S. 1992. The Siructure of Corporate Polucal Acuon: Interfirm Relanons and The't Consequences, Cambridge. MA: Harvard Un. versity Press

Mizruchi, M S 1993 Cohesion. Equivalence, and Similarity of Behavor: A Theoretical and Empirical Assessment Soczal Notitorks 15. 275-3017

Mizruchı. M S. 1994 What Do Interlocks Do' An Analyss. Crlluquc. and Assersment ut Research on Interlocking Directorates. Paper presented at the Annual Meeting of the Amert can Sociological Association. Los Angelen

Mizruchi. $\mathrm{M}$ S. Allison. D W A Polts. B B 1944. Individual and Structural Interests in Political Decision Makıng: A Theorellcal Discussion and Simulation Lnpublishod manuseript Department of Socrologs. I n versity of Michigan

Mizruchi, M S \& Galaskiewicz. J. 1943 Nel. works of Interorganizational Relations. Siste. loglcal Melhods and Re'search 22, th-70

Mizruchı. M S. Mariolıs. P. Schwartz, M d Mfintz, B lysio. Techniques for Draggregatung Centraluty Scores in Social Networki in N B

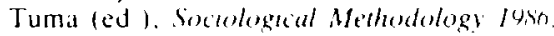
pp $2 n-48$ Washington American Sock. logical Association

Mizruchi. M S \& Stearns. L B 1444. A Longtudinal Study of Borrowing by Large Amerlcan Corporations Admmestrance Solente Quarterly 39. 118-1411.

Moore. G 1479 The Seructure of a Nationd Elite Network American Siciolegrical Re'te't 44. 67.3-69?

Moreno.J L 1934 Who Shall Surnere" Warh. ington. DC. Nervous and Mental Dresaxe Puh. lishing Company.

Nemenen, U. J. 1974 On Centrality in a Graph Scandmatian Journal of Psichoilon' 15, 32? 330

Palmer. D.. Barber. B. M. . Zhou, X. \& Soysal. Y. 1493 The Other Contested Terrain Ithe Friendly and Predatory Acquistion of Lares Corporations in the 19 fols. Paper presented al the Annual Meeting of the American Sock. logical Assuchation. Mamu Beach

Parsons, T 1951. The Socul Sirstem. New York Frece Press

Pettigrew. A M 1942. On Studying Managertal Elites. Sirategic Managemeni Jourmal 13. 10:$1 \times 2$.

Pfeffer, J. 1987. A Resource Dependence Pir. spective on Intercorporate Relations In M s Mizruchı \& M. Schwartz (eds.), Intercorporilt Relallons. pp 25-55. New York: Cambridgi University Pres

Powell, W W \& DiMaggro, P J (eds) [(4)] 
The New Instifuttonalism in Organzattonal Anulysis Chicago: Unuversity of Chicago Press

R.tcliff. R. E. 1980. Banks and Corporate Lending. An Analyss of the Impact of the Internal Structure of the Capitalist Class on the Lending Behavior of Banks. American Sociological Revlew. 45, 553-570.

juller, L D 1978 Structural Equivalence: Meaning and Definition, Computation and Application. Social Networks 1,73-90.

scrulli, D 1492. Theory of Societal Constlmutunalusm Foundations of a Non-Marxtst Critical Theory. New York: Cambridge Unıversity Prew

Sontt. J 1941 Socral Network Analysts: A Handhowk Newbury Park. CA: Sage Publications simmel, G (1417) 1950. The Triad. In K. H Wolff (ed.). The Sociology' of Gerorg Simmel. pp 145-164 New York: Free Press

Singh. H \& Hartanto. F. 1989. ManagementBoard Relationships. Takeover Rrsk, and the Adoption of Golden Parachutes Academ! of Vunagemeni Journal 32, 7-24.

Stearns. L B. \& Mizruchi, M S. 1993 Corporate Financing: Economic and Social Aspects In $\mathrm{R}$ Swedbere (ed ). Explorations in Econumic Sectology. pp 279-3117 New York: Russell Sage Foundation

Stephenson, $K$ \& Zelen, 11984 Rethinking Centrality: Methods and Examples Social Vetwerks $11,1-37$

Srokman. F N. \& Vian den Bos. J. M M1. 1942 A Two-Stage Model of Policymaking With an Empinical Test in the US Energy-Policy Dumain In G Moore \& J A Whitt leds). Reveurch in Polutics and Seredery. pp 219-253 Greenwich. CT JAI Press.

Swidler. A. losín Culture in Action Symbols and Strategen American Sochological Reven 51. $27.3-286$

lzz1. B D 1993. The Dynamies of OrganIzational Networks. Structural Embeddedness and Economic Behavior Ph.D dissertation. Department of Socrology, State Lnwersity of
New York at Stony Brook

Wade, J . OReilly, C. A. III \& Chandratat. I 19901. Golden Parachutes: CEOs and the Exercise of Social Influence. Admmistrative Sctence Quarterly 35, 587-6013.

Weesıe, J. \& Flap. H. (eds.) 1990 Socual Verworks Through Time Utrecht, Netherlands ISOR

Wellman. B 1988 Network Analysis: From Method and Metaphor to Theors and Substance. In B. Wellman \& S. D Berkowitz (eds). Socual Structures A Network Approach. pp 19-61 New York: Cambridge Unversity Press

White. D. R. \& Reitz, K. P 1983. Graph and Semigroup Homomorphisms on Networks of Relations. Social Nelworks 5. 193-234

White. H. C 1970. (hams of Opporlumuly Cambridge. MA Harvard University Press

White. H C 1488 Varietles of Markets In B Wellman \& S. D Berkowitz leds). Social Siructures A Network Approach, pp 2בh-2hil Neu York. Cambridge University Press

White. H. C. 1492a. Social Grammar for Culture Reply to Steven Brint. Serciological Theor 111. 2014-213

White. H C. 1942b. Identuly and Control At Structural Theory of Soctal Acton. Princeton. NJ. Princeton Universty Press

White. H C. 1993 Careers and Crean'my Sental Forces in the Arts Boulder. CO: Westrien

White. H C.Boorman. S. A. \& Breiger. R L 1976 Social Structure from Multiple Network, I - Blockmodels of Roles and Postion. American Journal of Soctology, 81, 731L7811

Williamson. O E. 1975 Marke's and Herarches thalysis and Anturuse lmplecatoms New York: Free Press

Williamson. O E. 1991 Comparatare Economic Organzation: The Analyss of Discrete Struc. tural Alternatives Admumstratue' Solence Quarterly 3h. 264-29h

Winship. C. |1473| 1988 Thoughts about Roles and Relations. An Old Document Revisted Socul Verturths 10, 209-231 